\title{
Victims of Untouchabilty in Sujatha Gidla's Ants among Elephants
}

\author{
G. Vishal Sridhar \\ M. Phil. Research Scholar in English \\ Goverment Muthurangam Arts College, Vellore, Tamil Nadu, India \\ (D) https://orcid.org/0000-0003-2229-7450
}

Manuscript ID:

ENG-2020-09013397

\begin{abstract}
The article examines the lives of Dalits in contemporary India with specific reference to Sujatha Gidla's Ants Among Elephants. She had exposed the reality of socio-economic nature of India where the struggles of Dalits cannot be expressed in words. The atrocities committed against the community are still continuing with strong political support. It also examines the themes of exploitation, marginalisation, and untouchability. The main objective is to analyse and expose the reality of casteism still prevailing in the modern era witnessed by development. It also concludes that education can be a source of emancipation from these social evils.
\end{abstract}

Month: December

Keywords: Untouchabilty, Caste, Dalit, Poverty, Atrocities, Injustice, Prejudice, Education Abbreviations: AAE - Ants among Elephants.

Year: 2020

P-ISSN: 2320-2645

E-ISSN: 2582-3531

Received: 27.08 .2020

Accepted: 15.10 .2020

Published: 01.12.2020

Caste system is a major hindrance for the development of our country. Untouchability is a social evil. Personal hygiene should be the deciding factor whether to touch a person or not. But practicing untouchability on the basis of caste is absurd. The practice of untouchability not only marginalises the untouchables but also alienates the caste Hindus from the Dalits.

Some people put forward the idea of deleting caste in the school agendas saying it may eradicate casteism. But ironically casteism was predominant in educational institutions. At work place if the employees find out the caste of his co-worker to be a Dalit he will be ignored by them. They cannot tolerate a person from a Dalit community to progress in life. They want to exploit him as their ancestors did to their forefathers.

Citation:

Vishal Sridhar, G.

"Victims of Untouchabilty in Sujatha Gidla's Ants among Elephants." Shanlax International Journal of English, vol. 9, no. 1, 2020, pp. 25-28.

DOI:

https://doi.org/10.34293/ english.v9i1.3397

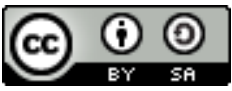

This work is licensed under a Creative Commons Attribution-ShareAlike 4.0 International License

Dalit literature is rooted in the philosophy of Ambedkar, which envisions Dalit emancipation and empowerment through a democratic, social and political revolution. Dalit radicals like Ambedkar believed that caste cannot be reformed and hence had to be eliminated, Gandhi, just as the social reformers of the nineteenth century, held the view that caste is an essential element of Hindu society and it could be made more humane by eliminating its evil practices like untouchability. The early historians of caste argue that untouchability springs from the low profile jobs the Dalits are condemned to perform such as scavenging, removal of dead animals, skinning them and removal of excreta.

Sujatha Gidla was born an untouchable. Her family, belonging to the Mala caste was educated in Warangal and Madras by Canadian Missionaries in the 1930's making it possible for Gidla to attend elite schools and move to America at the age of twenty-six. It was only then that she saw how extraordinary and yet how typical her family history truly was. Determined to uncover that history and understand the social and political forces that made it possible she travelled back to India to record the testimonies of her mother, her uncles, and their friends. In Ants among Elephants, She tells their story. 
Gidla's mother, Manjula, and uncles Satyam and Carey were born in the last days of British rule. They grew up in a world marked by poverty and injustice, but also full of possibility. In the slums of Elwin Peta in Kakinada, where they lived, everyone had a political bent: and rallies,agitations, and arrests were commonplace. The independence movement offered promises of freedom foreign rule, from want, and from social oppression. Yet, for untouchables and other poor and working people, little changed.

Satyam, the eldest, switched allegiance to communist party. Gidla recounts his incredible transformation from student and labor organizer to famous poet and co-founder of the People's War Group, the most notorious and successful Naxalite party. Gidla also charts her mother's battles with caste and women's oppression. Page by page, she takes us into a complicated, close-Knit family as they desperately strive for a decent life and a more just society. A moving portrait of love, hardship, and struggle, Ants among Elephants is also that rare thing: a personal history of modern India told from the bottom up.

The novel's central figure is K.G. Satyamurthy, maternal uncle of Sujatha Gidla. Satyam was a revolutionary poet in Andhra who wrote under the pen name Shivasagar. He was the founder of PWG (People's Warfare Group) a Naxalite guerrilla movement along with Kondapalli Seetharamaiah. He worked with important communist political leaders like Charu Mazumdar from West Bengal and was involved in the famous Srikakulam movement, an uprising of village peasants against the local landlords and leading to the formation of separate state of Telangana.

Satyam's family belong to the untouchable Mala community in the Khambam region of Andhra Pradesh. Satyam's father Prasanna Rao and his mother Maryamma were both educated by the Canadian Christian missionaries and they worked as teachers in the missionary school. They were converted into Christianity by the missionary.

Casteism was the reason for most of the Indian untouchables to convert to Christianity from Hinduism. But even within the Christian community casteism was in practice as evidenced by Sujatha's statement that the fair looking Christian girls from
Kerala would look down on her and won't even talk to her.

The Khambam family faced abject poverty in their life because of their lower caste and their exploitation by other caste Hindus. When Satyam was a boy he was beaten up by another boy for wearing trousers. The boy belongs to the Golla community, cattle - herding caste - a low caste, but even the lowest of caste Hindus are superior to untouchables.

The lower caste untouchable men were not allowed to wear shirts and sandals in front of the upper caste Hindus. The untouchables had to remove their shirt and sandals and carry it in their hands when they go through an upper caste locality.

Women in untouchable community were not allowed to cover their breasts by wearing blouses or with sarees. Specifically, in the state of Kerala, Dalit women had to pay tax according to the size of their breasts.

The Dalits were forced to wear dirty, rugged clothes belonging to dead persons. If they wear neat and white clothes they will be confronted by the upper caste men and got beaten up.

In a web article titled 'The Changing fabric of Dalit life' published on 21 April 2017 , it's author Ashwaq Masoodi talks about the dress code repression made against the Dalits by the other caste Hindus and registers the events of Dalit abuse.

Ajai Singh, 37 years old from Rasoolpur, Bulandshahr, says he was privileged as he could go to school and afford more than just a pair of clothes. But on his way to school one day in 1991, he passed by a lane inhabited by Rajputs. As always, his shirt was tucked into his navy blue pants and his hair, well oiled, was parted on the left. An upper caste man came up to him, pulled out his tucked-in shirt, sprung open the top two buttons of his shirt, tousled his hair and said, "Remember, You are a Dalit".

In January 2017, a Dalit man in Karnataka was beaten up, stripped and then forced to wear a dead man's clothes (The New Indian Express, 27 January). In 2015, a 22-year-old was thrashed for folding up his lungi while crossing an upper caste street in Tamil Nadu (The New Indian Express, October 2015). In 2012, a Dalit n Haryana was beaten up for wearing a white shirt (Dainik Bhaskar, May 2012). In 2006, 
a Dalit in Rajasthan was assaulted for wearing new jeans and a T-shirt (The Times of India, July 2007).

In Ants among Elephants both Prasanna Rao and his wife Maryamma worked as teachers in Christian missionary school. After his wife's death Prasanna Rao raised his children with the help of his motherin-law Marthamma.

They lived in a poor hut and its walls are made of mud. The house was poorly furnished and it has only one cot. Once there was a storm during the night time and the roof of the hut flew away. Prasanna Rao's family and his neighbour's families took shelter inside the school. They asked permission from the local authority to build houses for themselves near the school and they were granted permission but on one condition that they must live in a secluded place as they are untouchables.

Today the Dalits face difficulties to find houses for rent. If the neighbours find out that a tenant is a Dalit they will give pressure to the house owner to make the Dalits to vacate their house. They are not ready to live among the Dalits. So nobody will give houses for rent to a Dalit family.

Even if you are a well-educated person with gentle look but if you are a Dalit, you are still prone to the hatred and aversion of other caste Hindus. It doesn't matter whether one live in a village or a city, wherever he goes his caste follows him and it is difficult to hide or get rid of one's caste in India.

At the introduction of the novel Sujatha talks about this caste prejudice. She says that

In your own town or village, everyone already knows your caste; there is no escaping it. But how do people know your caste when you go elsewhere, to a place where no one knows you? There they will ask you, "What caste are you?" You cannot avoid this question. And you cannot refuse to answer".

After finishing high school Satyam joined the Andhra Christian College to study B.A. English. Satyam was so embarrassed and felt alienated among the other students because of his poor family background and his lower caste. He couldn't pay his mess fees so he would skip his meals and nobody would talk to him that he spent much of his time in the college library.
Satyam was ashamed that his classmates might have seen his name posted at the entrance of the mess hall. He had no money for books or lab records or term fees or exam fees. He couldn't afford to dress the way the students were supposed to, in shirt and pants. The strap of his thongs was broken and secured by a safety pin that kept coming undone. So he stopped going to classes.

(AAE 50)

Dalit students from poor family background face many hardships in colleges. One of the main things is the inferiority complex, while seeing other rich students belonging to upper caste will make them feel inferior and it affects them psychologically and thus consequently leading to their poor performance in their academics.

The theme of casteism and caste prejudice is paramount in the episodes of Sujatha's mother Manjula. She was humiliated and ostracized both in the college and in her working places. While studying at the Benares Hind University the head of the department of history reduced her marks for no other reason than she was a Dalit.

After graduating Manjula had to go to work to support her brother Satyam and his family as they are dependent on the only source of her income. But her job was not a permanent one and it was under constant threat. She was humiliated by the principal of the college she works at on the basis of her caste.

Manjula's only hope was to marry someone who would bring about a drastic change in her life. But her marriage to Prabhakara Rao was a disastrous one when she found out that he was 8 years older than her. He will constantly beat her in the presence of his mother to prove his manlinesss and show his mother that he is not henpecked. Thus Sujatha's mother Manjula was subjected to domestic violence and the patriarchal society in India is reflected through these episodes of the novel. Manjula's struggle to find a constant job and to raise her children on her own will move the readers to tears.

In the Dalit community men worked as hard labour and coolies for daily wages. Most of the Dalit men were unemployed and thus becoming drunkard will go on to create domestic violence by beating their wives. 
William Carey, Satyam's younger brother was poor in education and fails in the English subject. Carey was typical of a prodigal son who chases after girls but is very fond of her sister Manjula. He won't let her little sister to do household chores. He was living like a gangster and involves in fight. He is typical of a Dalit youngster who lacks the awareness of education and getting into fights. But in his later life Carey becomes a Physical education teacher.

A twelfth standard Dalit student was allegedly tied to a tree and beaten by two men in Gujarat's Patan district on the afternoon of March 18, 2109. According to an FIR registered on Wednesday, the 17 year-old boy from Mehsana was attacked in Gorad village while he was on his way to give the English board exam.

Mitkumar Nareshbhai Chavda lodged a case and stated in the FIR that he had reached the examination centre, Sarvajanik Vidya Mandir High School in Dhinoj village from his home town in Mehsana by state transport bus around $1 \mathrm{pm}$. While waiting outside the exam center Ramesh Patel whom he knows by face and a state transport conductor came to him and asked Mitkumar to come with him as he had some work. He took him to another person who was waiting with a motorcycle.

They both rode him to a nearby farm in Gorad village where they tied him to a tree and beat him. While beating him they told him that as a Dalit he should not write board exams and he should only do labour works. Even if the Dalits are willing to go to school the caste Hindus won't let them to study because they won't let the Dalits to develop socioeconomically in their lives.
The only way by which Dalits can protect themselves against atrocities towards them by the upper caste people is through education. But now it has all changed due to the influence of British colonial rule. Everyone has equal access to education. What is the use for a caste Hindu when he reads world's influential literary works but does get significance of Liberty, Equality and Fraternity and goes on to oppress and abuse Dalits, forbidding their human rights.

\section{Reference}

"Ants Among Elephants." Wikipedia, https:// en.wikipedia.org/wiki/Ants_Among_ Elephants

Chaudhuri, Amit. "Ants Among Elephants by Sujatha Gidla Review - Life as an 'untouchable' in modern India." The Guardian, 2018, https:// www.theguardian.com/books/2018/aug/02/ ants-among-elephants-sujatha-gidla-amitchaudhuri

Geeta. "An Area of Darkness: Review of 'Ants among Elephants...'." The Hindu, 2017, https://www. thehindu.com/books/books-reviews/an-areaof-darkness/article19777287.ece

Gidla, Sujatha. Ants among Elephants: An Untouchable Family and the Making of Modern India, Harper Collins Publishers. 2017.

"Sujatha Gidla." Wikipedia, https://en.wikipedia. org/wiki/Sujatha_Gidla

"Untouchability." Wikipedia, https://en.wikipedia. org/wiki/Untouchability

\section{Author Details}

G. Vishal Sridhar, M.Phil., Research Scholar in English, Government Muthurangam Arts College, Vellore, Tamil Nadu, India, Email ID: g.vishalsridhar1992@gmail.com. 